\title{
Bronchoscopic evaluation of peripheral lung tumours
}

\author{
R J SHINER, J ROSENMAN, I KATZ, N REICHART, B HBRSHKO, A YBLLIN

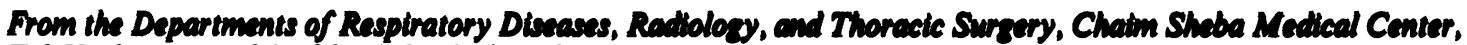 \\ Tel-Hashomer, and Sackler School of Medicine, Tel-A viv Untwersity, Tet-A wiv, Iereal
}

Asstract The results obtained from fbreoptic bronchoscopy performed under fluoroscopic guidance were evaluated in a prospective study of 71 coneccutive patients with a peripheral lung leaion more than $2 \mathrm{~cm}$ in diameter on the chest radiograph. A peripheral lung lesion was defined as a leation that was not seen within the bronchial tree at fibreoptic bronchoscopy. Small volume washinge, bronchoalveolar lavage, transbronchial biopay, and bronchial bruahinges were carried out and fuid or tissue was sent for cytological or histolo rical examination as appropriate. Of the 71 patients, 51 were subeequently shown to have malignant diceace. In 38 of the patients the diagnosis of malignancy was made by bronchoscopy, from histological specimens alone or in conjunction with cytological specimens in 33, from brushings alone in two, and from bronchoalveolar lavage fuid alone in three patients. There were no important complications. Thus fibreoptic bronchoscopy in conjunction with fluoroscopic cereening appears to be an effective and afe method for the initial inveatigation of a peripheral lung lesion more than $2 \mathrm{~cm}$ in diameter.

\section{Introduction}

Controverny exists about whether the fint dingmoatic procedure in the investigation of a peripheral lung ledion chould use the percutaneous or the bronchocopic approach. With peripheral leaions $2 \mathrm{~cm}$ or leas in diameter the diagnostic yield has been shown to be low regardleas of the technique. ${ }^{\text {th }}$

In this atudy we have examined the value of fibreoptic bronchoceopy under fluoroscopic cereening in the diagnosis of peripheral lung leatons more than $2 \mathrm{~cm}$ in diameter.

\section{Mottods}

Westudied 71 concecutive patients (62 outpatients and nine inpatients) referred to the reepiratory dicease cervice from January 1985 to May 1986 with a peripheral lung lecion more than $2 \mathrm{~cm}$ in dinmeter on the cheat radiograph. A peripheral lesion was defined as one that was not ceen within the bronchind tree at fibreoptic bronchoccopy. The lung felds were divided into central and peripheral zones, the central zone being defined as being within $4 \mathrm{~cm}$ radius of the hilum.'

Addren for correspondences Dr R J Shiner, Brompton floepital, London SW/3 6HP. (Reprints will not be avallable)

Acrepted 18 Angurt 1908
Bronchoceopy was carried out by an experienced bronchoscopint. Bach patient underwent umall volume wahinge, bronchoalveolar lavace, tranebronchial blopey, and bronchial brunhing, in that order. Two or three small volume $(5 \mathrm{ml})$ ealine bronchil wahes of the relevant area were performed. Single plane fuorocopy was uned for broschoalveolar lavage, trane. bronchid biopsy, and brushing. Bxnct localiention of the ledion was determined by advancement of the biopay forcepe vis the bronchocoppe with the patient firt in the anteroposterior and then in the lateral position (the patient being rotated without any movement of the bronchoscope or forceps). Movement of the tip of the biopey forceps in close sesocintion with the ledion on deep inspiration in both anteroposterior and lateral positions was uned to confirm cocurate poditioning. The patient was then returned to the anteroposterior position and the forceps were withdrawn. Bronchoalveolar lavage was performed without moving the bronchoscope by injecting $100 \mathrm{ml}$ of ealine in aliquots of $20 \mathrm{ml}$. Washinges and bronchoalveolar lavace fuid were cent for baco teriological and cytolocical exnmination. The fuid cent for cytolocical examination was centrifured and the cediment emeared on to four alidee, which were feed and stained by the Papanicolnou technique. Four to $\mathrm{dix}$ tranebronchinl biopay epecimens were taken, placed in formallin, dehydrated, embedded in paramin, and atnined with heematoxylin and coain. Bronchial brushing was performed with a nylon brush (Olym- 
Shiner, Rosenman, Katz, Reichart, Hershko, Yellin $\stackrel{\mathscr{X}}{\times}$

pus), which was smeared on to four slides that were fixed and stained by the Papanicolaou technique. Bronchoscopy was not repeated in any of the patients.

Results

Of 71 patients who underwent bronchoscopy during the 16 months, $51(72 \%)$ were subsequently found to have malignant disease. The patients with malignant disease had a mean age of 64 (range 43-85) years and 29 were male. The 20 patients with benign disease had a mean age of 60 (range 23-78) years and 10 were male.

The non-malignant group of 20 patients included five with surgically proved benign disease, two with pulmonary tuberculosis, and 10 whose lesion regressed and subsequently disappeared during follow up. Three patients have been followed for more than 24 months, with no change in the size of the lesion on the chest radiograph.

Of the 51 patients in whom malignant disease was diagnosed the diagnosis was obtained by bronchoscopic techniques in 38 (table 1). Both centrally and peripherally located tumours were diagnosed by bronchoscopy. Of the 13 patients with malignant disease in whom bronchoscopy gave negative results, nine were diagnosed at surgery and one at follow up examination of sputum cytology and in four patients the diagnosis was established from the clinical progression and subsequent evidence of malignant disease at other sites.

Of the 38 patients with malignancy diagnosed by bronchoscopy, 30 had a primary bronchogenic carcinoma, seven a tumour that had metastasised from another site (three breast, two large bowel, one bladder, one uterus) and one a non-Hodgkin's lymphoma. Of the 30 patients with a primary bronchogenic carcinoma, 10 had a squamous cell carcinoma, nine an adenocarcinoma, six a large cell carcinoma, and five a non-small cell carcinoma (a more specific classification was not possible). The tumour was resected in 12 of these patients; in one the histological classification was revised from squamous cell to large cell carcinoma and in another from squamous cell carcinoma to adenocarcinoma. The nine patients in
Table 2 Results of bronchoscopic diagnostic techniques in 38 patients with malignant tumours

\begin{tabular}{|c|c|c|}
\hline $\begin{array}{l}\text { Diagnostic } \\
\text { technique }\end{array}$ & $\begin{array}{l}\text { No }(\%) \text { of } \\
\text { positive } \\
\text { diagnoses }\end{array}$ & $\begin{array}{l}\text { Number where } \\
\text { sole source of } \\
\text { diagnosis }\end{array}$ \\
\hline \multicolumn{3}{|l|}{ Histology: } \\
\hline $\begin{array}{l}\text { Biopsy } \\
\text { Cytology: }\end{array}$ & $33(87)$ & 16 \\
\hline $\begin{array}{l}\text { Brush } \\
\text { Lavage } \\
\text { Small volume wash }\end{array}$ & $\begin{array}{r}19(50) \\
9(24) \\
5(13)\end{array}$ & $\begin{array}{l}2 \\
3 \\
0\end{array}$ \\
\hline
\end{tabular}

whom malignancy was diagnosed at surgery hadêे adenocarcinoma (three), large cell carcinoma (three), squamous cell carcinoma (two), and atypical carcinoidoo (one).

Histological examination showed malignant cells in응 33 of the 38 patients (table 2) and 22 of these were bothhistologically and cytologically positive. In five patients malignancy was diagnosed from cytology alone, in three from bronchoalveolar lavage fluid 3 alone and in two from bronchial brushings alone. The small volume wash provided a diagnosis in five patients but in none was it the sole source of diagnosis. 0

Bronchoscopy caused few complications in the $71^{\circ 0}$ patients-there was a small pneumothorax in one patient (not requiring a chest drain) and smalls haemoptyses in a few patients.

\section{Discussion}

Bronchoscopy with fluoroscopic guidance made as diagnosis possible in 38 of the 51 patients with ar peripheral malignant lesion more than $2 \mathrm{~cm}$ inp. diameter on the chest radiograph. We selected lesions of this size as our previous experience with smallex lesions had been disappointing, as noted by others. ${ }^{2}$ In contrast, percutaneous needle aspiration of tumours; with a diameter of $2 \mathrm{~cm}$ or less may give twice the diagnostic yield of bronchoscopic procedures. ${ }^{45}$

Twenty patients had benign lesions and in 10 o these inflammatory changes were seen on lung biopsy응 These findings taken together with the clinical presen $\rightarrow$ tation prompted a conservative approach, consisting.

Table 1 Diagnostic yield (No of diagnoses/No of examinations) for benign lesions and malignant tumours* in relation to size and position

\begin{tabular}{|c|c|c|c|c|c|c|c|}
\hline \multirow[b]{2}{*}{ Size of tumour $(\mathrm{cm})$ : } & \multicolumn{3}{|c|}{ Central location } & \multicolumn{3}{|c|}{ Peripheral location } & \multirow[b]{2}{*}{ Total } \\
\hline & $2-4$ & $4-6$ & $6-8$ & $2-4$ & $4-6$ & $6-8$ & \\
\hline $\begin{array}{l}\text { Malignant } \\
\text { Benion: }\end{array}$ & $6 / 8$ & $7 / 7$ & $4 / 5$ & $9 / 13$ & $10 / 15$ & $2 / 3$ & $38 / 51$ \\
\hline $\begin{array}{l}\text { Benign: } \\
\text { Inflammation } \\
\text { Other conditions } \dagger \\
\text { Total }\end{array}$ & $\frac{2 / 2}{8 / 10}$ & $\frac{1 / 1}{8 / 8}$ & $\begin{array}{l}\overline{0 / 1} \\
4 / 6\end{array}$ & $\begin{array}{c}6 / 6 \\
0 / 6 \\
15 / 25\end{array}$ & $\begin{array}{c}3 / 3 \\
0 / 1 \\
13 / 19\end{array}$ & $\overline{\overline{2}}$ & \} $12 / 20$ \\
\hline
\end{tabular}


of antibiotic treatment and close follow up. Antituberculous treatment was initiated in two patients in whom tuberculosis was confirmed. Unlike others, ${ }^{6}$ we did not correctly diagnose peripherally situated non-malignant conditions such as sarcoidosis.

Left upper lobe lesions proved more difficult to diagnose correctly by the transbronchial approach (a positive diagnosis in only six out of 12 patients) and this is probably related to the eccentric position of the segments of the left upper lobe. There were no appreciable differences between the yields from other lung regions.

The bronchoscopic approach allows visualisation of the tracheobronchial tree and we confirmed the low complication rate reported by others (pneumothorax $0.01 \%$, haemorrhage $0.01 \%$ ). ${ }^{6-8}$ In contrast, percutaneous needle aspiration results in pneumothorax in 20 $30 \%$ of cases. ${ }^{9-11}$ Of these, a third to a half require chest tube drainage..$^{10}$ Rarer complications of aspiration needle biopsy include air embolism ${ }^{12}$ and implantation of tumour in the needle track. ${ }^{13}$

In our study 33 of the 38 diagnoses of malignancy were made by histological examination of transbronchial biopsy material. The yield is similar to that reported in other studies ${ }^{67}$ and provides a clear advantage over needle aspiration, which usually obtains material for cytological examination only. Because of the high complication rate from trephine air drill biopsy ${ }^{14}$ needle aspiration is the percutaneous technique of choice for peripheral and intrathoracic lesions in most centres. ${ }^{15}$

Our diagnostic yield was improved by the cytological analysis of bronchoalveolar lavage fluid and bronchial brush specimens. Small volume washings were not the sole source of a diagnosis of malignancy in any patient and should probably be replaced by bronchoalveolar lavage in the investigation of peripheral lung tumours.

In our opinion bronchoscopy with transbronchial biopsy and brushing under fluoroscopic control appears to be the best initial procedure for the investigation of peripherally placed tumours over $2 \mathrm{~cm}$ in diameter. Bronchoalveolar lavage should also be performed and the lavage fluid analysed for malignant cells.

We would like to thank Drs Herczeg, Gur, and Baum for their help in this study.

\section{References}

1 Radke JR, Conway WA, Eyler WR, Kvale PA. Diagnostic accuracy in peripheral lung lesions. Chest 1979; 76:176-9.

2 Stringfield JT, Markowitz DJ, Bentz RR, Welch MH, Weg MH. The effect of tumor size and location on diagnosis by fiberoptic bronchoscopy. Chest 1977;72: 474-6.

3 Cortese DA, McDougall JC. Biopsy and brushing of peripheral lung cancer with fluoroscopic guidance. Chest 1979;75:141-5.

4 Wallace JM, Deutsch AL. Flexible fiberoptic bronchoscopy and percutaneous needle lung aspiration for evaluating the solitary pulmonary nodule. Chest 1982 ; 81:665-71.

5 Berquist TH, Bailey PB, Cortese DA, Miller WE. Transthoracic needle biopsy, accuracy and complications in relation to location and type of the lesion. Mayo Clin Proc 1980;55:475-81.

6 Mitchell DM, Emerson CJ, Collins JV, Stableforth DE. Transbronchial lung biopsy with a fibreoptic bronchoscope: analysis of results in 430 patients. $\mathrm{Br} J$ Dis Chest 1981;75:258-62.

7 Whiteman AJA, Douglas AC. Flouroscopically-controlled transbronchial biopsy of solitary peripheral lesions using the fibreoptic bronchoscope. Clin Radiol 1978;29:621-4.

8 Smiddy JF, Eliott RC. Complications of fiberoptic bronchoscopy. Am Rev Respir Dis 1974;109:67-72.

9 Westcott JL. Direct percutaneous needle aspiration of localized pulmonary lesions: results in 422 patients. Radiology 1980;137:31-5.

10 Sagel SS, Ferguson TB, Forrest JV, et al. Percutaneous transthoracic aspiration needle biopsy. Ann Thorac Surg 1978;26:399-405.

11 Cortese DA. Solitary pulmonary nodule, observe, operate, or what? Chest 1982;81:662-4.

12 Westcott JL. Air embolism complicating percutaneous needle biopsy of the lung. Chest 1973;63:108-10.

13 Wolinsky H, Lischner MW. Needle tract implantation of tumor after percutaneous lung biópsy. Ann Intern Med 1969;71:359-62.

14 Herman PG, Hessel SJ. The diagnostic accuracy and complications of closed lung biopsies. Radiology 1977;125:11-4.

15 Loke J, Matthay RA, Ikeda S. Techniques for diagnosing lung cancer. A critical review. Clin Chest Med 1982; 3:321-9. 